\title{
TO THE ISSUE ON THE HYGIENIC SAFETY OF MODERN MOTOR FILLING STATIONS BY THE LEVEL OF THEIR IMPACT ON THE EWVIRONMENT
}

Mohylnyi S.N., Makhniuk V.M., Zorina O.V., Gorval A.K.

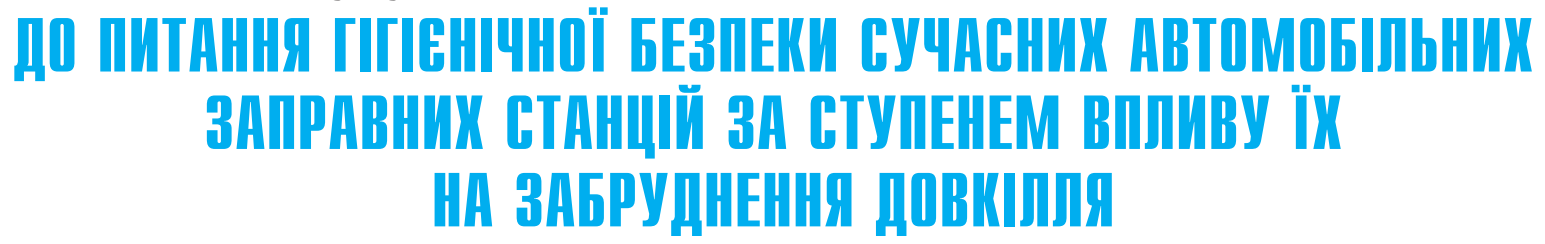

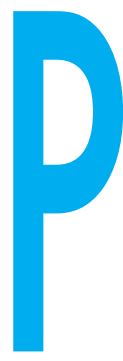

МОГИЛЬНИЙ С.М.,

МАХНЮК В.М., 3OPIHA O.B.,

ГОРВАЛЬ А.К.

ДУ «Інститут громадського здоров'я ім. О.М. Марзєєва

НАМН України», м. Київ

УДК $614: 711.553: 625.748 .54$

Ключові слова: гігієнічна безпека, сучасні автомобільні заправні станції, забруднення довкілля, санітарно-захисна зона. івень автомобілізації є одним 3 основних показників економічного розвитку країни та якості життя населення. Поняття «автомобілізація» - це комплекс технічних засобів та інфраструктура 3 обслуговування автомобілів: автомобіль - дорога - технічне обслуговування автомобільна заправна станція.

Автомобільний транспорт та промисловість $€$ основними джерелами забруднення атмосфери. Частка автотранспорту у загальних викидах шкідливих речовин у містах може сягати $60-80 \%$. Понад 80\% усіх викидів в атмосферу становлять викиди оксидів вуглецю, діоксиду азоту, діоксиду сірки, вуглеводнів, твердих частинок, недиференційованих за складом.

Стрімка автомобілізація сучасного суспільства зумовлює розвиток інфраструктури 3 обслуговування автомобілів, передусім автомобільних заправних станцій (АЗС), функціонування яких, окрім впливу фізичних факторів на довкілля, пов'язане $з$ викидами в атмосферне повітря від технологіч- ного обладнання (приймальнороздавальні колонки, насоси тощо) та від автомобілів під час його руху (в'їзд/виїзд). Усе зазначене поєднано діє на навколишнє природне середовище та прилеглу сельбищну територію. Вивчення цих питань у санітарно-гігієнічному відношенні є актуальним.

Метою дослідження $€$ вивчення гігієнічних питань безпеки сучасних автомобільних заправних станцій та розробка заходів з мінімізації шкідливого впливу їхньої діяльності на навколишнє середовище сельбищних територій.

Об'єктами досліджень були автомобільні заправні станції малої та середньої потужності, які $€$ найбільш поширеними в Україні. Дослідження проводили на автозаправних станціях міст Київ, Вінниця, Полтава та Житомир, які є експериментальними майданчиками згідно з договорами про співпрацю між ДУ «ІГЗ НАМНУ» та ПП «НОРМА-Д» (№ 33 від 18.07.2016), ТОВ «Українська компанія - ВВ» (№ 34 від 18.07.2016), ТОВ «МОБІЛГАЗ»
К ВОПРОСУ ГИГИЕНИЧЕСКОЙ БЕЗОПАСНОСТИ СОВРЕМЕННЫХ АВТОМОБИЛЬНЫХ

ЗАПРАВОЧНЫХ СТАНЦИЙ ПО СТЕПЕНИ ИХ ВЛИЯНИЯ НА ЗАГРЯЗНЕНИЕ ОКРУЖАЮЩЕЙ СРЕДЫ

Могильный С.Н., Махнюк В.М., Зорина О.В., Горваль А.К.

ГУ «Институт общественного здоровья им. А.Н. Марзеева НАМН Украины», г. Киев

Целью работы было изучение гигиенических вопросов безопасности современных автомобильных заправочных станций и разработка мер по минимизации вредного воздействия их деятельности на окружающую среду селитебных территорий.

Методы: экспертной оценки, санитарно-эпидемиологической экспертизы, санитарно-гигиенические, аналитические, санитарно-статистические. Результаты. В статье представлены результаты комплексных исследований по гигиенической безопасности современных АЗС малой и средней мощности по степени их влияния на загрязнение окружающей среды.
Вывод. Доказана достаточность нормативной санитарно-защитной зоны в 50 м для автозаправочных станций малой и средней мощности по таким критериям: наличие современного транспортного парка; наличие современного оборудования с противопожарными технологиями; соблюдение на внешней границе СЗЗ, обращенной к жилой застройке, концентраций загрязняющих веществ и уровней вредных факторов, не превышающих их гигиенические нормативы; уровень обеспечения санитарно-гигиенических условий труда для работников АЗС и потребителей; благоустройство и озеленение территории АЗС; организация въездных и выездных групп на территории АЗС с соблюдением санитарных разрывов; проведение мероприятий по предупреждению психогенной нагрузки на жителей прилегающей застройки.

\section{Ключевые слова: гигиеническая} безопасность, современные автомобильные заправочные станции, загрязнение окружающей среды, санитарно-защитная зона.

() Могильний С.М., Махнюк В.М., Зоріна О.В., Горваль А.К. . СТАТТЯ, 2018. 
the contamination of the environment are presented in the article.

Conclusions: Normative sanitary-and-protective zone of $50 \mathrm{~m}$ is sufficient for motor filling station of small and middle power by the criteria: exist of modern motor park; exist of modern equipment with fire-preventive technologies; adherence to the concentrations of the pollutants and levels of hazardous factors not exceeding their hygienic standards on the external boundaries of sanitaryand-protective zones near residential building; level of the supply with sanitary-and hygienic conditions for the labor of MFS workers and consumers; improvement and planting of greeneries of MFS territories; organization of entry and exit groups at the MFS territories taking into account sanitary gaps; implementation of the measures for the prevention of psychogenic load on the residents of the adjoining building.

Keywords: hygienic safety, modern motor filling stations, environmental contamination, sanitary-and-protective zone. on the hygienic safety of modern MFS of small and middle power by the level of their impact on

(№ 38 від 08.08.2016) та БКП «СТРОЙМОНТАЖ ЛТД»-ТОВ (№ 39 від 08.08.2016).

у роботі були використані методи експертної оцінки, санітарно-епідеміологічної експертизи, санітарно-гігієнічні, аналітичні, санітарно-статистичні.

Результати. За останні 10 років рівень автомобілізації в Україні різко зріс і становить 202 індивідуальні автомобілі на 1000 населення. За цим показником Україна посідає 71 місце серед країн світу і за рейтинговим розподілом стоїть після Казахстану (219 авто/1000 осіб), при цьому випереджаючи Республіку Молдову (156 авто/1000 осіб) та Грузію (155 авто/1000 осіб). Рейтинговий розподіл окремих країн світу за показником кількості індивідуальних автомобілів, що припадають на 1000 осіб, наведено у таблиці 1 [1].

Аналізуючи дані таблиці 1, можна констатувати, що розвинуті країни Європи, такі як Німеччина з населенням 81,2 млн., Велика Британія 3 населенням 63,4 млн., Республіка Польща з населенням 63,4 млн. мають показник автомобілізації на 1000 осіб у 2,2-2,4 рази менший, ніж у Сан-Марино, що пояснюється мобільністю населення - широким використанням велосипедного транспорту, здоровим способом життя та свідомим ставленням до охорони навколишнього природного середовища. В Україні цей показник нижчий майже втричі порівняно 3 європейськими країнами.
Рейтинговий розподіл окремих областей України за показником кількості індивідуальних автомобілів, що припадають на 1000 осіб, наведено у таблиці 2.

Зазначений показник автомобілізації по Україні - найвищий у м. Києві, який становить 343 авто/1000 осіб та пояснюється вищим рівнем життя (середня заробітна плата по м. Києву 15 тис. грн.) порівняно з іншими областями. Майже на одному рівні з цим показником перебу-

вають Київська (343 авто/1000 осіб), Запорізька (246 авто/ 1000 осіб) та Волинська (203 авто/1000 осіб) області.

у зв'язку з підвищенням рівня автомобілізації населення країни зростає кількість АЗС. 2012 року їх нараховувалося 1034, 2013 р. - 1443, 2016 р. ця кількість без урахування Донецької та Луганської областей становила 3600, а 2018 р. - 3792. Кількість діючих АЗС в Україні по обласних

Таблиця 1

Рейтинговий розподіл окремих країн світу за показником кількості індивідуальних автомобілів, що припадають на 1000 осіб, та даними щодо їхньої площі території та кількості населення

\begin{tabular}{|c|c|c|c|c|}
\hline $\begin{array}{c}\text { Рейтингове } \\
\text { місце }\end{array}$ & Країна & $\begin{array}{c}\text { Авто/ } \\
1000 \text { осіб }\end{array}$ & $\begin{array}{c}\text { Кількість } \\
\text { населення }\end{array}$ & Площа, км² \\
\hline 1 & Сан-Марино & 1263 & 33030 & 61 \\
\hline 2 & Монако & 899 & 37860 & 2 \\
\hline 3 & США & 797 & 327631340 & 9519431 \\
\hline 10 & Італія & 679 & 60795600 & 301340 \\
\hline 12 & Канада & 662 & 36048500 & 9984670 \\
\hline 15 & Іспанія & 593 & 46468100 & 505990 \\
\hline 16 & Японія & 591 & 126225000 & 377944 \\
\hline 20 & Німеччина & 572 & 81292400 & 357021 \\
\hline 23 & Литва & 560 & 2826500 & 65301 \\
\hline 27 & Польща & 537 & 38422350 & 312679 \\
\hline 34 & Велика Британія & 519 & 63395600 & 243809 \\
\hline 46 & Білорусь & 362 & 9491800 & 207600 \\
\hline 57 & $P \Phi$ & 293 & 146880430 & 17125190 \\
\hline 67 & Казахстан & 219 & 18157100 & 2724902 \\
\hline 71 & Україна & 202 & 42248600 & 603549 \\
\hline 89 & Молдова & 156 & 3550900 & 33846 \\
\hline 90 & Грузія & 155 & 3729600 & 69700 \\
\hline 188 & Ліберія & 3 & 4294000 & 111369 \\
\hline
\end{tabular}


містах та населених пунктах показано на рисунку.

За останні 10 років змінилася технологія будівництва АЗС, відійшли у минуле радянські АЗС $з$ декількома колонками під навісом без будь-яких елементарних гігієнічних умов (відсутність водопостачання, каналізування, санітарно-побутових умов тощо). Будівництво сучасних АЗС європейського зразка передбачає використання сучасних технологій заправки паливом та зберігання палива і розширення функцій надання послуг споживачам з елементами обслуговування транспортних засобів, водіїв та пасажирів [2, 3].

За чинним нормативним документом санітарного законодавства «Державні санітарні правилаі планування та забудови населених пунктів. ДСП № 173-96», затвердженим наказом Міністерства охорони здоров'я України від 19.06.1996 р. № 173, зареєстрованим у Міністерстві юстиції України 24.07.1996 р. № 379/1404/ (п. 5.32), для АЗС встановлена нормативна санітарно-захисна зона (С33) розміром у $50 \mathrm{~m}$ [4]. Зазначений норматив С33 не враховує категорії АЗС, їхн потужність і режим роботи, природоохоронні заходи. Також диференціювання відсутнє щодо використання кількості видів палива, об'ємів ємності для зберігання палива та розміщення їх (наземне чи підземне).

Відповідно до класифікації АЗС за ДБН «Планування і забудова міських і сільських поселень. № 360-92**» [5] АЗС поділяються на категорії залежно від потужності та розміщення резервуарів відносно

Розподіл окремих областей України за показником кількості індивідуальних автомобілів, що припадають на 1000 осіб, та даними щодо їхньої площі території та кількості населення

\begin{tabular}{|l|c|c|c|}
\hline \multicolumn{1}{|c|}{ Область України } & $\begin{array}{c}\text { Авто/ } \\
1000 \text { осіб }\end{array}$ & $\begin{array}{c}\text { Кількість } \\
\text { населення }\end{array}$ & $\begin{array}{c}\text { Площа, } \\
\text { км² }^{2}\end{array}$ \\
\hline м. Київ & 343 & 2934522 & 847,66 \\
\hline Київська область & 255 & 1732200 & 28121 \\
\hline Запорізька область & 246 & 1765930 & 27183 \\
\hline Волинська область & 227 & 1043220 & 20144 \\
\hline Дніпропетровська область & 203 & 3285630 & 31923 \\
\hline Донецька область & 179 & 4320820 & 26517 \\
\hline Херсонська область & 164 & 1055650 & 28461 \\
\hline Чернігівська область & 131 & 1054626 & 31903 \\
\hline
\end{tabular}

водопостачання, каналізації тощо)

Усі досліджувані об'єкти АЗС розташовувалися на земельних ділянках уздовж магістральних вулиць і доріг поблизу житлової та громадської забудови 3 дотриманням нормативної СЗ3 у 50 м від найближчих джерел викидів АЗС до найближчої існуючої індивідуальної житлової забудови, що відповідає вимогам ДСП № 173-96 (п.5.32) [4] та ДБН № 360-92** (пп. 7.55-7.57) [5].

На діючих АЗС, що досліджувалися, широко використовувалася реклама продажу пального 3 конструкціями, обладнаними неоновими лампами з ефектом мерехтіння. У зв'язку з цим реєструвалися скарги від населення прилеглої житлової забудови на дратівливість та погіршення самопочуття. Після перенесення рекламних конструкцій (щитів) на протилежну від житлової забудови територію та заміну освітлювальних ламп без ефекту мерехтіння скарги населення припинилися.

у 100\% випадків досліджувані АЗС були забезпечені централізованим водопостачанням та каналізуванням, якість питної води відповідала за хімічними та бактеріологічними показниками вимогам Державних санітарних норм та правил «Гігієнічні вимоги до води питної, призначеної для споживання людиною. ДСанПіН 2.2.4-171-10».

Організованими джерелами забруднення атмосферного повітря на типових (традиційних) АЗС були дихальні клапани резервуарів, які об'єднані між собою сучасною системою, що дозволяє зменшити загальну кількість джерел викидів; приймальні паливні пристрої для зливу палива із паливовозів; пістолети паливнозаправних колонок та паливні люки автомобілів, що заправляються. На окремих АЗС за рахунок облаштування резервних дизель-електростанцій та власних газових котелень додатковими джерелами забруднення повітряного середовища були димові труби відповідних агрегатів.

Для постачання палива на досліджуваних АЗС використовувався сучасний транспорт паливовози, які замінили застарілий парк паливного спецавтотранспорту, що об- 
лаштовані системами рекуперації парів пального із резервуарів до паливовозу, що витісняються при зливі пального із автоцистерни до резервуару, і значно зменшує викиди так званих «великих дихань» від резервуарів.

Раніше найбільший вклад у забруднення атмосферного повітря від АЗС формувався за рахунок використання застарілого автопарку та старої технології заповнення порожніх резервуарів пальним із паливовозів, коли пари пального викидались із резервуарів в атмосферне повітря.

При впровадженні сучасного обладнання на АЗC, за розрахунковими даними, викиди від їхніх джерел забруднення становлять від АЗС малої потужності 0,181-3,179 т/рік (за середніх величин 1,106 т/рік) та від АЗС середньої потужності - 0,145-5,012 т/рік (за середніх величин 1,590 т/рік). Основними специфічними забруднюючими речовинами від роботи АЗС $€$ бензин, вуглеводні насичені (вуглеводні насичені $\mathrm{C}_{1}-\mathrm{C}_{5}$, вуглеводні насичені $\mathrm{C}_{6}-\mathrm{C}_{10}$, бензол, ксилол, толуол, етилбензол) та гас. Від роботи двигунів автомобілів викидаються забруднюючі речовини (діоксид азоту, оксид вуглецю).

Розрахункові максимальні концентрації специфічних забруднюючих речовин в атмосферному повітрі у районі розміщення АЗС малої потужності становили (ГДК - гранично допустима концентрація) на відстані

$\square 25$ м: бензину - 0,65, вуглеводнів - 0,43, гасу - 0,79;

口 40 м: бензину - 0,52, вуглеводнів - 0,55, гасу - 0,66;

口 50 м: бензину - до 0,27, вуглеводнів - 0,30, гасу - 0,45.

Сумарні показники забруднення атмосфери, розраховані за максимальними концентраціями усіх забруднюючих речовин (бензину, вуглеводнів та гасу) у межах нормативної С33 становили на відстані 25 м 0,98 ГДЗ, 40 м - 0,88 ГД3, 50 м - 0,50 ГДЗ, що оцінюється як допустимий рівень забруднення згідно з Методичними рекомендаціями «Оцінка ризику для здоров'я населення від забруднення атмосферного повітря. MP 2.2.12-142-2007» [7].

Забруднення атмосферного повітря у зоні впливу АЗС середньої потужності за мак- симальними концентраціями специфічних речовин становили (ГДК) на відстані

口 40 м: бензину - 0,80, вуглеводнів - 0,51;

口 50 м: бензину - 0,45, вуглеводнів - 0,45.

За максимальними концентраціями усіх забруднюючих речовин (бензину та вуглеводнів) сумарний показник забруднення атмосферного повітря у межах нормативної С33 становив на відстані 40 м - 0,59 ГД3, 50 м - 0,47 ГДЗ. Очікуваний рівень забруднення атмосферного повітря у зоні впливу АЗС оцінюється як допустимий і безпечний [7].

За матеріалами натурних досліджень атмосферного повітря, проведених територіальними підрозділами обласних лабораторних центрів МО3 України у районі впливу окремих АЗС різної потужності, встановлено: на межі нормативної санітарно-захисної зони розміром 50 м у зоні впливу АЗС малої потужності забруднення атмосферного повітря діоксидом азоту, оксидом вуглецю та насиченими вуглеводнями реєструвалися на рівні 0,03-0,80 ГДК, у зоні впливу АЗС середньої потужності - на рівні 0,24-0,80 ГДК, що не перевищували відповідні їхні гігієнічні нормативи. Рівень

Кількість діючих автомобільних заправних станцій по обласних містах України та населених пунктах станом на 2018 рік

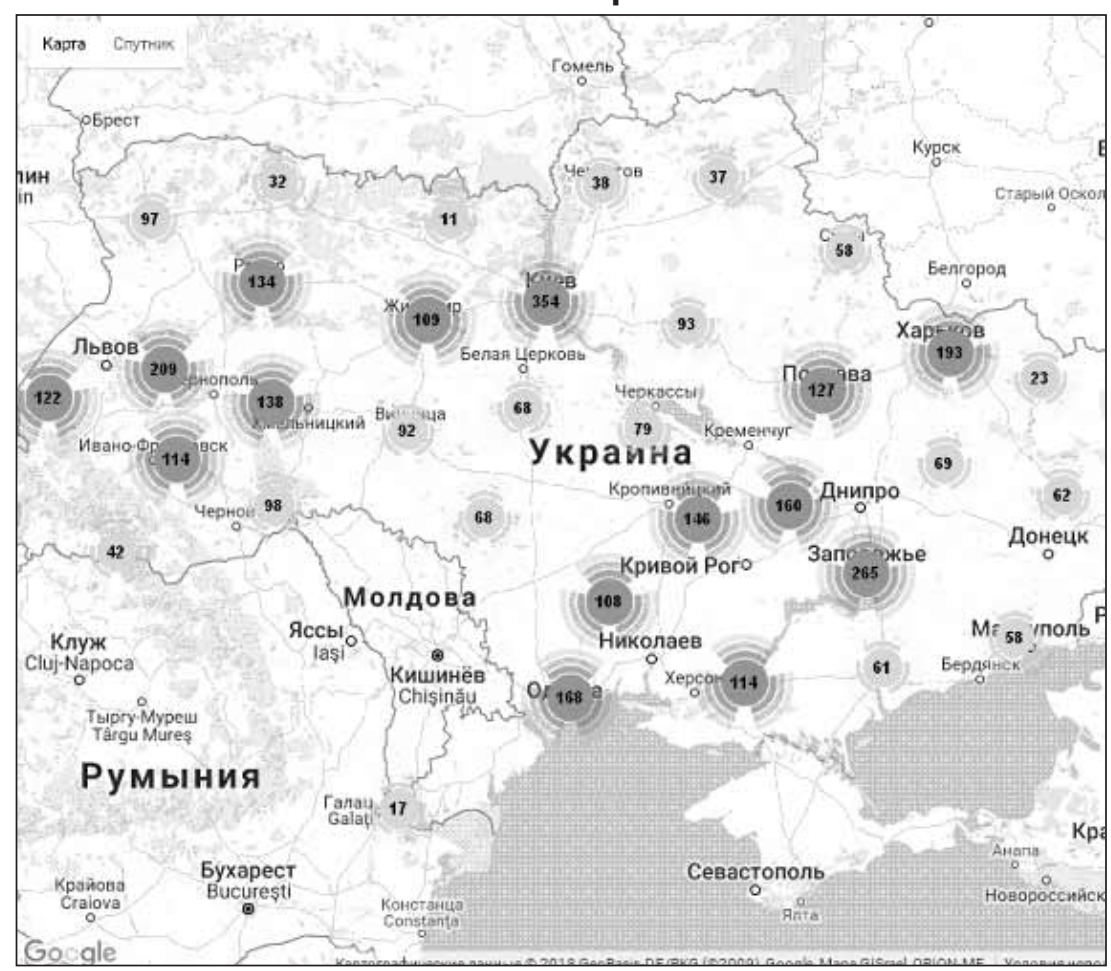

сумарного забруднення атмосферного повітря, розрахований за цими даними, оцінювався як допустимий і становив для АЗС малої потужності 0,76 ГДЗ, для АЗС середньої потужності - 0,84 ГДЗ [7].

Таким чином, розрахункові і фактичні концентрації основних забруднюючих речовин від АЗС малої потужності, починаючи з 25 м, та від АЗС середньої потужності, починаючи 3 40 м, не перевищували гігієнічні нормативи і за сумарним показником забруднення атмосфери у частках ГДЗ були оцінені як безпечні.

За розрахунковими даними проектів та натурними дослідженнями АЗС, загальні рівні шуму на прилеглій сельбищній території на відстані 50 м відповідали вимогам ДСП № 17396 (Додаток № 16) та ДБН 360 $92^{* \star}[4,5]$.

Через наявність на АЗС значних обсягів бензину різних марок, які належать до легкозаймистих рідин, дизельного палива, які належать до горючих рідин, АЗС віднесені до об'єктів, що можуть становити вибухо- та пожежонебезпеку не тільки для персоналу і водіїв 3 пасажирами, а й для населення прилеглої житлової забудови. Відповідно до вимог ДБН 36092** (таблиця 7.9*) нормативні

Рисунок . 
пожежні відстані для АЗС становлять для АЗС малої потужності 25 м; для АЗС середньої потужності - 40 м, що у $100 \%$ випадків досліджуваних АЗС були дотримані $[3,6]$.

\section{Рекомендації}

Для зменшення впливу на забруднення довкілля атмосферного повітря від функціонування АЗС розроблено та пропонуються до впровадження такі санітарно-епідеміологічні та архітектурно-планувальні рішення:

$\square$ облаштування резервуарів для зберігання рідкого палива з'єднувальними комунікаціями з подвійними стінками та апаратурою для контролю над можливим витіканням палива у поміжстіночний простір;

облаштування резервуарів автоматизованими пристроями для недопущення переливання палива та швидкороз'ємними муфтами для герметичного зливання палива із цистерни паливовоза;

口 впровадження системи уловлювання викидів із резервуара під час його заповнення рідким паливом шляхом витискання його парів у звільнений об'єм автоцистерни-паливовоза (байпаси);

в впровадження паливороздавальних, заправних і газозаправних колонок спеціальної конструкції, що забезпечують герметичне з'єднання заправного пристрою 3 горловиною паливного бака або газового балона автомобіля і вакуумне відсмоктування парів палива у газовий простір резервуара;

в віддалення в'їзної/виїзної групи на території АЗС на нормативну відстань від житлових та громадських споруд та впровадження заходів шумозахисту (екран, озеленення);

дотримання нормативних пожежних відстаней та забезпечення сучасних протипожежних технологій;

$\square$ впровадження заходів щодо попередження психогенного впливу на мешканців прилеглої житлової та громадської забудови.

\section{Висновок}

На підставі комплексних досліджень питань гігієнічної безпеки сучасних автозаправних станцій доведено достатність нормативної санітарнозахисної зони у 50 м для автозаправних станцій малої та середньої потужності за такими критеріями: наявності сучасного транспортного парку; наявності сучасного еколого-збережного обладнання $з$ протипожежними технологіями; дотриманням на зовнішній межі санітарнозахисної зони, зверненої до житлової забудови, концентрацій забруднюючих речовин та рівнів шкідливих факторів, що не перевищують їхні гігієнічні нормативи, і рівнем забезпечення санітарно-гігієнічних умов праці для працівників та споживачів; благоустрою та озеленення території АЗС; організації в'їзних та виїзних груп на території АЗС з дотриманням санітарних розривів; впровадженням заходів щодо попередження психогенного навантаження на мешканців прилеглої забудови.

\section{ЛІТЕРАТУРА}

1. Івасенко В.М. Вдосконалення методів та засобів вимірювання концентрацій шкідливих речовин у викидах автозаправних станцій : автореф. дис. .. канд. техн. наук: спец.

05.11.13 - прилади і методи контролю та визначення складу речовин. К., 2016. 21 с.

2. Bogucki J. Najm odszy klient na stacji paliw. Na Stacji Paliw. 2017. № 2 (7). S. 6-9. URL: https: //nastacjipaliw.pl/pl/archiwum.

3. Mohylnyi S.M., Makhniuk V.M., Chernychenko I.O., Lytvychenko O.M. Risk approach to sanitary-and-epidemiological assessment of the location of modern filling stations. Довкілля та здоров'я. 2017. № 2 (82). С. 35-38.

4. Державні санітарні правила планування та забудови населених пунктів: ДСП №173-96. Збірник важливих офіційних матеріалів з санітарних і протиепідемічних питань. 1996.

Т. 5. 4. 1. С. 8-93.

5. Містобудування.

Планування та забудова міських і сільських поселень: ДБН 360$92^{\star \star}$. К. : Укрархбудінформ, 2002. $92 \mathrm{c}$

6. Могильний С.M.

Планувальні рішення об'єктів інфраструктури автомобільних доріг (на прикладі автозаправних станцій). Актуальні питання гігієни та екологічної безпеки України (XIII марзєєвські читання) : зб. тез доп. наук. -практ конф. К., 2017. Вип.17.

C. $46-48$.

7. Оцінка ризику для здоров'я населення від забруднення атмосферного повітря : метод. рек. МР 2.2.12-142-2007. К. : МОЗ України, 2007. 28 с.

\section{REFERENCES}

1. Ivasenko V.M. Vdoskonalennia metodiv ta zasobiv vymiriuvannia konzentratsii shkidlyvykh rechovyn u vykydakh avtozapravnykh stantsii : avtoref. dys. ... kand. tekhn. nauk [Improvement of the Methods and Means for the Measurement of the Concentrations of Hazardous Substances in the Emissions of Motor Filling Stations: Thesis Abs. Cand. Techn. Sci.]. Kyiv ; 2016 : 21 p. (in Ukrainian).

2. Bogucki J. Na Stacji Paliw. 2017. № 2 (7). S. 6-9. URL: https://nastacjipaliw.pl/pl/archiwum.

3. Mohylnyi S.M., Makhniuk V.M., Chernychenko I.O. and Lytvychenko O.M. Dovkillia ta zdorovia. 2017 ; 2 (82) : 35-38.

4. Derzhavni sanitarni pravyla planuvannia ta zabudovy naselenykh punktiv : DSP №173-96 [State Sanitary Rules for Planning and Building od the Settlements: DSP №173-96]. In : Zbirnyk vazhlyvykh ofitsiinykh materialiv z sanitarnykh i protyepidemichnykh pytan [Collection of the Important Official Materials on Sanitary and Antiepidemic Issues]. 1996; 5 (1) : 8-93 (in Ukrainian).

5. Mistobuduvannia. Planuvannia ta zabudova miskykh i silskykh poselen : SBS $360-92^{\star *}$. [Town Planning. Planning and Building of Urban and Rural Settlements : DBN 360-92**]. Kyiv :

Ukrarkhbudinform ; 2002 : 92 p. (in Ukrainian).

6. Mohylnyi S.M. Planuvalni rishennia obiektiv infrastruktury avtomobilnykh dorih (na prykladi avtozapravnykh stantsii)

[Planning Solutions of the Objects of the Infrastructure of Motor Ways (Example of Motor Filling Stations]. In :

Aktualni pytannia hihiieny ta ekolohichnoi bezpeky Ukrainy (XIII marzieievski chytannia) : zb. tez konf. [Actual Issues of Hygiene and Ecological Safety of Ukraine

(The Thirteenth Marzeiev's Reading) : Conf. Abstract Collection]. Kyiv ; 2017 ; 17 : 46-48 (in Ukrainian).

7. Otsinka ryzyku dlia naselennia vid zabrudnennia atmosfernoho povitria : metod. rekomendatsii MR 2.2.12-142-2007 [Assessment of the Risk for the Health of the Population from Ambient Air Pollution : Method. Recommendations MR 2.2.12142-2007]. Kyiv : Ministry of Health of Ukraine ; $2007: 28$ p. (in Ukrainian).

Надійшло до редакції 21.04.2018 